\title{
MODERNIZATION OF CURRICULUM IN CONSTRUCTION MANAGEMENT BASED ON EU FUNDS
}

\section{J. PASLAWSKI ${ }^{1}$, R. MILWICZ ${ }^{2}$, P. NOWOTARSKI ${ }^{3}$}

\begin{abstract}
The need for modernization of curricula is growing with the development of new technologies to support teaching, changes in business strategy of universities in Poland and European Union, and development of the society. In response to these changes, at the Department of Civil and Environmental Engineering at Poznan University of Technology, new English-language specialty master studies - Construction Technology Management was launched in March 2014. Studies are based on the cooperation between the student, the industry and the university, allowing students to get to know the specifics of the construction industry. In addition, Poznan University of Technology is involved in an MBAIC project MBA in construction aimed at common study for postgraduates. The synergy achieved through the implementation of these two projects enables the possibility to educate construction managers capable of communication in English, possessing knowledge regarding innovation in the construction industry, who are well prepared to enter the labour market and have the possibility of subsequent improvement of managerial competences.
\end{abstract}

Keywords: MBA for construction managers, modernization of the curriculum, construction technology management, the new approach in the education of engineers.

\section{INTRODUCTION}

Currently, the Faculty of Civil and Environmental Engineering (FCEE) at the Poznan University of Technology (PUT) participates in two international projects related to the modernization of curricula of teaching construction managers connected with creating new learning opportunities.

\footnotetext{
${ }^{1}$ Prof., DSc., Eng., Poznań University of Technology, Faculty of Civil and Environmental Engineering, ul. Piotrowo 5, 61-138 Poznan, Poland, e-mail: jerzy.paslawski@put.poznan.pl

${ }^{2}$ MSc., Eng., Poznań University of Technology, Faculty of Civil and Environmental Engineering, ul. Piotrowo 5, 61-138 Poznan, Poland, e-mail: roman.milwicz@put.poznan.pl

${ }^{3}$ MSc., Eng., Poznań University of Technology, Faculty of Civil and Environmental Engineering, ul. Piotrowo 5, 61-138 Poznan, Poland, e-mail: piotr.nowotarski@put.poznan.pl
} 
Projects are focused on the introduction of strong relationships between the student and the industry partners of the university, and the introduction of new curricula taking into account opinions from different points of view (universities, partners from the industry, professional organizations, alumni, students, etc.). The whole idea is connected to the introduction of new subjects in the studies related to the use of theoretical knowledge in practice (e.g. Flexibility in Engineering Design - lectures by the professor from the MIT) and the preparation of innovative materials for MBA Studies. Projects are carried out by the Institute of Structural Engineering (Division of Construction Technology and Management), at PUT in cooperation with universities, engineering associations and companies from Poland and abroad. The article is a short presentation of two projects, which are currently in progress and partially finished, with presentation of expected results and possibilities for further actions that can be achieved together with partners from other universities and industries from all over Europe. During the work on those projects, people involved had always kept in mind the possibility of cooperation with academic institutions, professional associations of engineers and managers, as well as promoting the idea of engineers who feel the need to expand their knowledge, which is very important in practical and theoretical education of civil engineering managers.

\section{DESCRIPTION OF THE PROJECTS CURRENTLY BEING IMPLEMENTED AT THE FCEE}

The important issues for the education of engineers-managers in the field of construction are primarily, signalled by the engineer's organizations (regional associations of engineers) and organizations of companies operating within the construction industry (regional chambers of construction), as a discrepancy between the expected competencies of graduates engineers and master's programs in construction. Those problems can be associated with: lack of interpersonal skills, lack of competences connected with entrepreneurship and innovation, limited practical experience, limited competences in modern technologies (IT, mobile technologies, energy management), very limited language skills (the requirement is a minimum of two languages - English + e.g. German, French, Spanish, others), insufficient international experience.

The often discussed question regarding how universities should prepare students to work on a particular position, and how the training should be targeting general education (which is often signalled as advantage of our graduates working abroad). Of course, it is possible to solve this dilemma by implementing special programs taken from professional and dual studies. 
However, in the analysed case, measures have been taken to address identified deficiencies through the modernization of the curriculum at the level of master studies by:

- introduction of teaching in English (which also allows to create an attractive offer for students from other countries - including non-EU),

- creation of a permanent cooperation with companies in the construction industry (including companies operating outside of Poland),

- cooperation with other universities - national (University of Economics, Adam Mickiewicz University in Poznan, Warsaw University of Technology) and foreign (Massachusetts Institute of Technology, Free University of Bozen-Bolzano), and the industry bodies,

- cooperation with engineers-managers organizations (Chamber of Civil Engineers) and contractors (Chamber of Construction),

- establishing a system of internships in partner companies (with training period minimum 3 months, which seems to be beneficial, from both students' and companies' point of view),

- gradual involvement of students in cooperation with business by: visits to enterprises (1st semester), summer internships (the involvement of students in solving ofreal problems in the enterprises) - (2nd semester), writing a thesis in direct cooperation with the enterprise (3rd semester),

- broadening the curriculum of subjects in the field of entrepreneurship and innovation (innovation and beyond the typical field of construction, including: IT, mobile and energy management),

- introduction of managerial games as a pro-active forms of entrepreneurial education,

- increasing the number and range of elective subjects.

An important element of the described modernization of learning processes is taking part in projects in co-operation at the city level, regional, the European Union and beyond, which allows to define common problems, achieve new powers, find new teaching methods and promote good practice. Cooperation with industry significantly broadens horizons, has a positive effect not only on improving the standards of teaching, but also on the development of academic staff involved in such projects. Fresh "outside" look at analysed problems and the ability to generate new ideas and consultations with partners in the projects, is a significant advantage, which undoubtedly improves the quality of the classes, enriching them with much-needed life examples that affect the interest of students in courses delivered in English. The chart presented below shows the number of applicants for studies carried out in English at the FCEE in the last 5 years. Since the opening of the first specialty 
- Structural Engineering conducted 100\% in English in the year 2010, through the creation of 2nd specialization Construction Technology Management (CTM) in 2013, until this day.

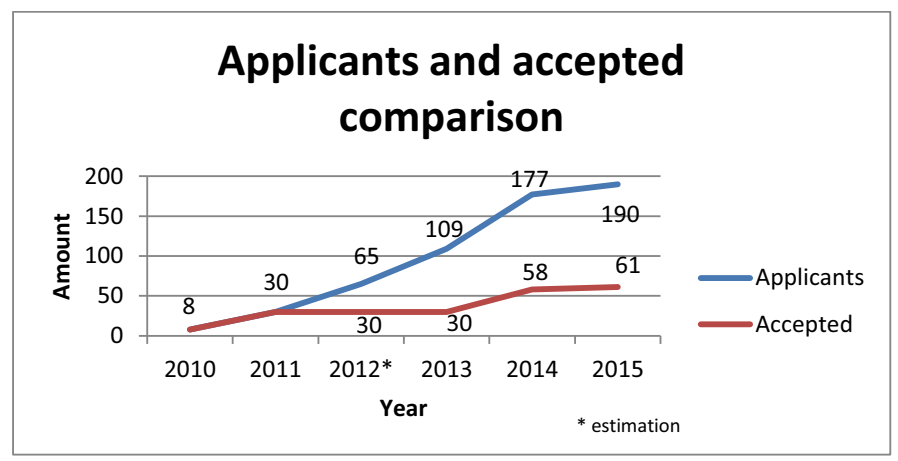

Fig. 1. Number of applicants and accepted for English-speaking courses at FCEE [15]

It can be observed, that each year the number of applicants for the English-speaking courses increased, reaching in 2015 the level of 190 people. In 2014 a 2nd course opened in English- CTM so that the maximum number of seats in the English-speaking groups has doubled. The authors believe that there is a similar trend in other European universities. Recognizing the undoubted advantages of cooperation and the growing demand for modern teaching methods delivered in English, Department of Construction Technology and Management of the Institute of Structural Engineering at the FCEE Poznan University of Technology participates in two projects related to education of managers in the construction industry, which are presented in this article.

\subsection{ProJect MBAIC - LeONARdo da VinCI 2013-1-PL1-LEO05-37822}

For some time now, the growing demand for qualified management staff can be noticed. Directors and specialists in the field of HR are increasingly looking for candidates with managerial skills and knowledge in a particular specialized field of construction. Proper response to the needs of the construction market is taking the initiative in the framework of the European projects by teaching centres and managerial organizations from different European countries (United Kingdom, Poland, Lithuania, Spain, Portugal), on the creation of international MBA programs for managers in the field of construction. Logo design is presented in Figure 2. The program is implemented in cooperation with the following centres: Warsaw University of Technology, Faculty of Civil Engineering (WUT) - Poland - project coordinator; Valencia Polytechnic University (PUV) - Spain; Vilnius 
Gedyminas Technical University (VGTU) - Lithuania; Poznan University of Technology (PUT) Poland; Polish Association of Building Managers (PSMB) - Poland; University of Minho (UMinho) - Portugal; The Chartered Institute of Building (CIOB) - United Kingdom.

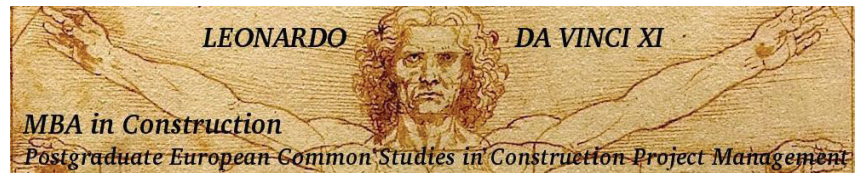

Fig.2. Logo of the MBAIC project.

The aim of the project is to prepare, and later start, postgraduate MBA studies in Construction Management for engineers and construction managers across Europe. The tasks carried out in the project, in addition to the preparation of programs tailored to the participants through contact with people who have completed similar courses, including future expectations, is testing the demand for this kind of studies on the EU market. Thanks to the EU funds it was possible to create a network of universities and other organizations, directly related to the construction and interested in creating joint degree program (graduate or MBA) with the possibility of receiving double degree (double diploma). In addition, thanks to the close cooperation with companies in Poland and other countries from the European Union, it was possible to identify future needs and skills of candidates (and employees) employed in many positions in the construction industry (laboratory, building site, office projects, finance, modernization of existing buildings, production of prefabricated elements, office design, foreign trade office, etc.). The project provides training in modular way by selecting by candidates issues and topics which are most important for them, with limitation of needed time to learn those topics. An important element of the project is an international collaboration between partners. It was developed as a new teaching methodology based on blended learning - partially via direct contact with the students, and partially via Internet Moodle system. This is especially important for the participants already working in enterprises for whom this program is dedicated. Opportunity to participate in activities, with the use of an active call options and on-line through mobile technologies is becoming is the main advantage of the described study, mainly because of the reduction of time needed in participating in the standard face- to -face meetings. The qualification recognition system is included in the framework of the Leonardo which is required in order to perform managerial functions in the construction sector in countries within the European Union. This system will be used to improve the curriculum and build the profile of graduates, with the use of concept of elective subjects and courses. Indicated at the beginning, the competence gap [14] exists mainly due to the fact that the traditional technical studies are focused on specific competencies. Therefore, measures 
have been taken to identify and assess the competence realizable during the second cycle studies [12, $11]$ and the requirements for different positions in this field. The problem of recognizing skills and qualifications is becoming more and more relevant because of the recognition of our students, who want to work for foreign companies and also the foreign students enrolled at PUT.. In order to develop new proposals ,as part of this project, various management qualification systems in the construction industry were reviewed $[1,4,13]$, taking into account both the period of study and the time of practice. In the present analysis the following suggestions were included:

- improving quality and attractiveness of the education systems [7],

- activation of actions to prevent social exclusion [8],

- including the involvement of women [2],

- identifying strategic actions by the Erasmus PLUS program focused on knowledge in the field of innovation and entrepreneurship [17],

- improving regional cooperation (university-industry-trade organizations) [20],

- increasing participation of students' own work, expand the offer of studies in English [16],

- introducing changes in teaching methods [19].

An important advantage of the project is the possibility to exchange experiences in the field of education between the partners-stakeholders from various centres. Analysis of the qualification system of construction managers in different countries allows developing a coherent European approach in this field. It should be mentioned that not only does the cooperation between universities take place, but also between institutions in the construction industry (CIOB, Polish Association of Construction Managers). The project is a continuation of actions taken in previous years and based on the results of projects LDV TOI CLOEMC I [3] and II [5] (PL/06/B/F/PP/174-014, 2009-1-PL1LEO05-05016) [10].

\subsection{Master in Construction Technology Management- Engineer for the FUTURE POKL.04.03.00-00-259/12}

The program is a part of a larger project [9], which aims to improve the educational potential of the Poznan University of Technology. Part carried out at the FCEE is related to the creation of new master studies in Construction Technology Management, which is conducted entirely in English. Course is an alternative to the existing studies at the faculty - master in Structural Engineering, focused on the training of future masters of engineering with a specialization in construction design, which was established as part of the project Engineer Era [6]. Within the new project, a program of study was 
created tailoring to the new assumptions. When selecting subjects, emphasis has been placed on cooperation with the construction industry and solving current problems of the construction companies. Figure 3 presents a grid of study, which was adopted by the council of the FCEE in December 2013, and which has received positive reviews by independent experts in the field of science and higher education, reviewing a new program of study [18].

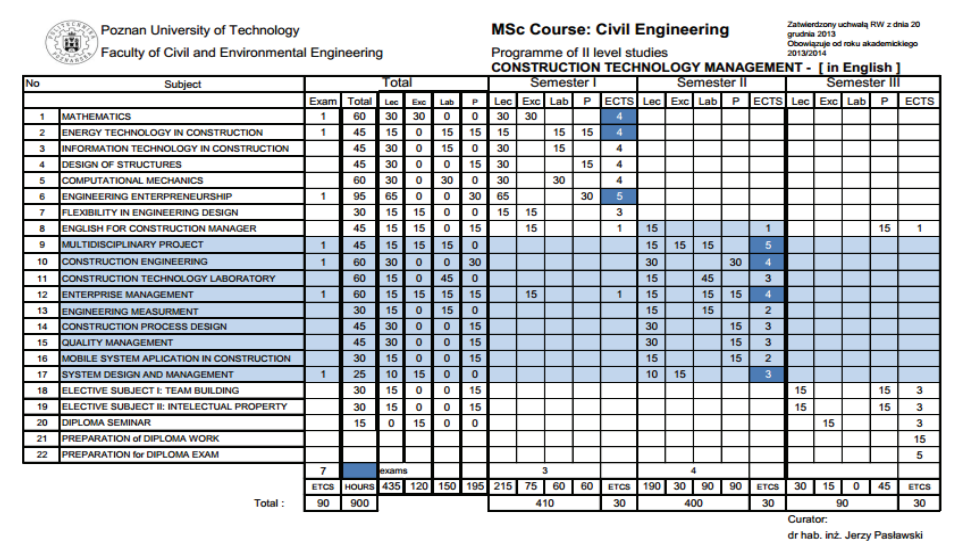

Fig. 3. Program of the master studies in Construction Technology Management.

The work carried out by students, together with representatives of companies is much more interesting to the students and encourages them to take greater interest in the topic and make them look for innovative solutions that are often later successfully used and implemented by the partner companies. In addition, a new method of teaching at the PUT was introduced in the form of video conferencing, using software e.g.: WebEx. For the first time in the history of PUT, it was possible to fully realize the subject of Flexibility in Engineering Design conducted by Professor Richard de Neufville from Massachusetts Institute of Technology, without the need for his physical presence at the university while delivering his lectures. Students during virtual meetings, on a regular basis, have the opportunity to ask questions and receive immediate access to the materials provided by the professor on the Moodle platform. The introduction of this type of lectures, created not only an increased interest among the students of a new form of teaching, but also made it possible to organize lectures with world-class specialist in flexibility at the PUT (Fig. 4). Now, with a very positive reaction from students, this solution was adopted to create a new set of virtual meetings with students and other scientific institutions collaborating with PUT in Europe (Bolzano - Italy and Helsinki Finland). 


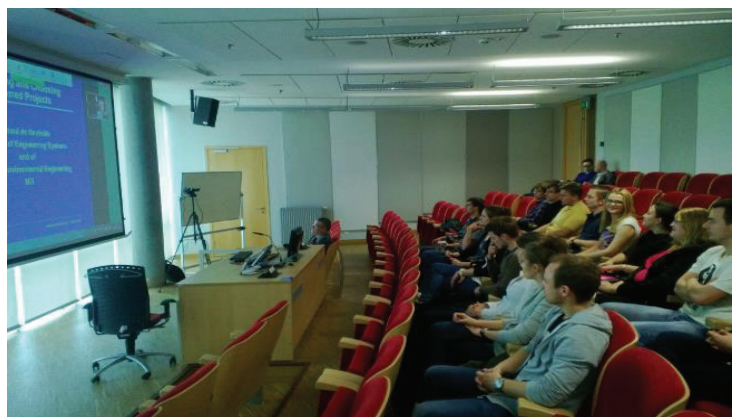

Fig. 4. Virtual meeting with prof. Richard de Neufville - MIT.

Particularly noteworthy are the innovative teaching methods used successfully by a guest from MIT. Lecture requires the active participation from students (students illustrated lecture with examples from practice). It should also be noted that the designed classes require much more independence and teamwork (exercises are discussed during the lectures). The student has the opportunity to demonstrate their creativity and activity, for which they are evaluated. Students can meet on campus to discuss the possibilities of a common solution to the problem, while progress of the project is estimated on the basis of individual reports after reaching a set of milestones. The project Engineer of the Future also provides a 3-month paid internships for students of CTM, through which the student learns how to operate a construction company, and has the ability to prepare a thesis in collaboration with the industry. Potential employer can assess potential employee skills and check them against various positions under different conditions. Based on the assessment results of student's internship, industry partner decides to continue their action in this direction offering a job place for student or terminates cooperation with them. After the first edition of internships in $2014,80 \%$ of the students were provided promises of job positions after graduation, which proves that the system of paid internships has positive impact on the possibility of finding a first job after graduation for students studying CTM field.

\section{CONCLUSIONS}

It can be said beyond doubt, that the implementation of projects carried out with financial support of the EU creates a new perspective for the curriculum for specialty Construction Technology Management. The implementation of two described projects made it possible to achieve the following benefits: 
1. Creating an attractive alternative option of master studies aimed at achieving new competencies for future construction managers (foreign languages, entrepreneurship, innovation, case study analysis, etc.).

2. The possibility for introduction of new teaching methods (activity-seminars during the lectures, teamwork) and technical solutions (on-line transmission of lectures from another university).

3. The staff development opportunities - both through the skills and contacts with partner centers and employment of new staff.

4. Establishing contacts with international trade organizations and international academia.

5. The delineation of further directions of cooperation in science in a situation to gain new partners

6. Increasing the prestige of specialty for the benefit of students, industry partners and employees.

7. the possibility of consolidating project's team around the idea of using teamwork.

Projects carried out at the Poznan University of Technology in the framework of EU funds help to increase the opportunities that the university can offer for current and future students and engineers. In addition, these projects are aimed at strengthening cooperation with the industry, which means that the university graduate is able to easily find a job and often transitions smoothly from the trainee to the employee of the company. Future offer of the university for teaching specialists will also be expanded to include MBA postgraduate studies in the field of construction, which will enable the systematic improvement of qualifications by our graduates. In addition, the staff of division and faculty involved in the preparation and implementation of projects, have the opportunity to make new contacts in Europe and the world, which has a positive impact on their research and teaching potential and creates new opportunities for growth and the creation of new joint projects.

\section{OTHER INFORMATION}

This publication was prepared within the framework of the Leonardo da Vinci Program 2013-1-PL1LEO05-37822 co-financed by the European Union under the European Social Funds. 


\section{REFERENCES}

1. AEEBC Association of European Building Surveyors and Construction Experts -, www: http://aeebc.org/eurbe, access 14 April 2015

2. D. Andriti, P. Gluch, M. Holmdahl, (2013) Managerial competences of female and male managers in the Swedish construction industry, Construction Management and Economics, Vol. 31(9), pp. 979-999

3. Bulletin of Leonardo da Vinci program, Vol. 8(1), pp. 24

4. CIOB, www: http://www.ciob.org/become-a-member, accessed 14th April 2015

5. Common Learning Outcomes for European Managers in Construction II \& III, www: http://aeebc.org/da-vinci, accessed: April 13th, 2015

6. The Era of Engineer [in Polish], www: http://www.ei.put.poznan.pl/projekt, accessed: April 13th, 2015

7. Erasmus+, www: http://erasmusplus.org.pl/o-programie/, accessed: April 13th 2015

8. Experts opinion regarding Master course in CTM - Construction Technology Management.

9. Engineer for the Future [in Polish], www: http://ip.projekt.put.poznan.pl/projekt/, accessed: April 15th, 2015

10. LDV MBAIC, http://www.leonardo.il.pw.edu.pl/ldvmbaic, accessed: April 12th 2015

11. E. Pellicer, V. Yepes.,A.J. Ortega, (2012) Designing a benchmark indicator for managerial competences in construction at the graduate level, , Journal of Professional Issues in Engineering Education and Practice, Vol. 138(1), pp. 48-54

12. E. Pellicer, V. Yepes.,A.J. Ortega, (2013) Method for planning graduate programs in construction management, Journal of Professional Issues in Engineering Education and Practice, Vol. 139(1), s. 33-41

13. PSMB, www: http://www.psmb.pl/karta-eurbe/, accessed: April 14th, 2015

14. A. Stabryla (Ed.), Overview of problems perfecting of enterprise management systems, Ed. Mfiles, Krakow 2011

15. Recruitment data form FCEE, Faculty of April 20th, 2015

16. Strategy for PUT development - horizon 2020 [in Polish], www: http://www3.put.poznan.pl/sites/default/files/uchwala-strategia.pdf, accessed: April 15th, 2015

17. Strategy Europe 2020, www: http://ec.europa.eu/europe2020/index_pl.htm, access 13th April 2015

18. Progress towards Europe 2020 targets, www: http://ec.europa.eu/europe2020/europe-2020-in-yourcountry/polska/progress-towards-2020-targets/index_en.htm, accessed: April 13th, 2015

19. R. Vilpisauskas, Does Europe 2020 represent learning from the Lisbon strategy? In: Cleeton D. E. (Ed.) Europe and national economic transformation: the EU after the Lisbon Decade, Series: Palgrave Studies in European Union Politics, 2012

20. Strategy of development of Wielkopolska Province to the year 2020.[in Polish], Attachment to the document no XXIX/559/12 of Wielkopolska Province Parliament from 17th December 2012, Poznań 2012M. Hall, Y. Djerbib, "Rammed earth sample production: context, recommendations and consistency", Construction and Building Materials 18: pp. 281-286, 2004.

\section{LIST OF FIGURES AND TABLES:}

Fig. 1. Number of applicants and accepted for English-speaking courses at FCEE.

Rys. 1. Ilość chętnych i aplikujących na kursy w języku angielskim na WBIIŚ.

Fig. 2. Logo of the MBAIC project.

Rys. 2. Logo projektu MBAIC.

Fig. 3. Program of the master studies in Construction Technology Management.

Rys. 3. Program studiów drugiego stopnia specjalności Construction Technology Management.

Fig. 4. Virtual meeting with prof. Richard de Neufville - MIT.

Rys. 4. Spotkanie wirtualne z profesorem Richardem de Neufville z MIT. 


\section{MODERNIZACJA PROGRAMÓW NAUCZANIA ZWIĄZANYCH Z ZARZĄDZANIEM PROCESAMI BUDOWLANYMI}

Stowa kluczowe: Studia MBA dla menedżerów budownictwa, unowocześnienie programu studiów, technologia i organizacja budownictwa, nowe podejście w edukacji inżynierów.

\section{STRESZCZENIE:}

Obecnie na Wydziale Budownictwa i Inżynierii Środowiska Politechniki Poznańskiej realizowane są dwa międzynarodowe projekty związane z modernizacją programów nauczania menedżerów budowlanych mające na celu stworzenie nowych możliwości kształcenia. Projekty ukierunkowane są na wprowadzenie silnych relacji pomiędzy studentem, partnerami z przemysłu a uczelnią oraz wprowadzanie nowych programów nauczania mając na uwadze opinie szerokich gremiów (uczelnie, partnerzy z przemysłu, organizacje branżowe, absolwenci, studenci, itp.). Wiąże się do także z wprowadzeniem nowych przedmiotów w programie studiów związanych z wykorzystaniem wiedzy teoretycznej w praktyce, oraz z przygotowaniem innowacyjnych materiałów dla potrzeb studiów MBA. Opisane projekty realizowane są w Instytucie Konstrukcji Budowlanych (Zakład Technologii i Organizacji Budownictwa) Politechniki Poznańskiej przy współpracy z uczelniami i ośrodkami zrzeszającymi inżynierów w kraju i za granicą.

Artykuł ma na celu krótką prezentację dwóch projektów, które w chwili obecnej są realizowane i znajdują się na półmetku, ich spodziewane efekty oraz perspektywy dalszych działań możliwych do realizacji wspólnie z partnerami z innych uczelni oraz przemysłu. Jednocześnie mamy na uwadze możliwości współpracy zarówno z ośrodkami akademickimi, izbami zrzeszającymi inżynierów i menedżerów, jak i rozpowszechnienie tej idei wśród inżynierów, którzy odczuwają potrzebę poszerzenia swoich kompetencji.

\section{Projekt MBAIC - Leonardo da Vinci 2013-1-PL1-LEO05-37822}

Celem projektu jest przygotowanie i następnie uruchomienie studiów podyplomowych MBA in Construction Management dla inżynierów i menedżerów budownictwa w całej Europie. Zadania realizowane w projekcie to, oprócz przygotowania programów dostosowanych do uczestników przez kontakt z osobami, które ukończyły podobne kursy, także przeprowadzenie badań oczekiwań przyszłych uczestników tego typu studiów. Dzięki pozyskanym środkom możliwe stało się wykreowanie sieci uczelni i innych organizacji związanych bezpośrednio z budownictwem zainteresowanych stworzeniem wspólnego programu studiów (podyplomowych lub MBA) z możliwością uzyskania podwójnego dyplomu (double-diploma). Ponadto dzięki ścisłej współpracy w przedsiębiorstwami, w Polsce i w innych krajach Unii Europejskiej, okazało się możliwe określenie wymagań i umiejętności przyszłych kandydatów (i pracowników) zatrudnionych na wielu stanowiskach (laboratorium, plac budowy, biuro projektów, kosztorysowanie, modernizacja istniejących obiektów budowlanych, produkcja materiałów budowlanych, itp.). W ramach projektu przewidziano kształcenie modułowe umożliwiające wybór przez kandydatów zagadnień najbardziej interesujących oraz ograniczenie czasu wyłączenia z aktywności zawodowej. Istotnym elementem projektu jest współpraca międzynarodowa pomiędzy partnerami. Opracowana została także nowa metodologia nauczania oparta o nauczanie mieszane (blended learning) - częściowo bezpośrednio w kontakcie ze studentami, a częściowo zdalnie za pomocą Internetu i systemu typu Moodle. Jest to szczególnie ważne dla uczestników już pracujących w przedsiębiorstwach, dla których dedykowany jest przede wszystkim ten program. Możliwość uczestniczenia w części zajęć przy wykorzystaniu opcji aktywnego połączenia on-line dzięki technologiom mobilnym staje się zdecydowanym atutem opisywanych studiów, ze względu na ograniczenia czasowe i kosztowe związane $\mathrm{z}$ dojazdem na spotkania na uczelni. 


\section{Studia Master w Construction Technology Management (CTM) - Inżynier Przyszłości POKL.04.03.00-00-259/12}

Program jest częścią większej projektu, który ma na celu poprawę potencjału dydaktycznego Politechniki Poznańskiej. Część realizowana na Wydziale Budownictwa i Inżynierii środowiska dotyczy stworzenia nowej opcji studiów Master in Construction Technology Management, która w całości prowadzona jest w języku angielskim. Kierunek jest alternatywą do prowadzonych już na wydziale studiów magisterskich specjalności Structural Engineering, nastawionych na kształcenie przyszłych magistrów inżynierów o specjalności konstrukcyjnej, która powstała w ramach realizacji projektu Era Inżyniera. W ramach realizacji projektu, powstał program studiów dostosowany do nowych założeń. Przy opracowaniu programu studiów główny nacisk został położony na współpracę $\mathrm{z}$ przemysłem budowlanym i rozwiązywanie aktualnych problemów występujących w przedsiębiorstwach budowlanych.

Prace realizowane przez studentów wspólnie z przedstawicielami przedsiębiorstw są zdecydowanie bardziej interesujące dla studenta i zachęcają do poszukiwania innowacyjnych rozwiązań, które mogą być z powodzeniem wykorzystywane i implementowane przez zainteresowane przedsiębiorstwa partnerskie.

Dodatkowo wprowadzono nowe metody nauczania na Politechnice Poznańskiej w postaci przedmiotów realizowanych w całości przy pomocy wideokonferencji i odpowiedniego oprogramowania, np.: WEBEX. Pierwszy raz w historii Poznańskiej uczelni, udało się w całości zrealizować przedmiot Flexibility in Engineering Design prowadzony przez profesora Richarda de Neufville'a z Massachusetts Institute of Technology, bez potrzeby fizycznego przebywania profesora na terenie uczelni w czasie prowadzenia zajęć. Studenci podczas wirtualnych spotkań mieli możliwość na bieżąco zadawania pytań oraz otrzymali bezpośredni dostęp do materiałów udostępnionych przez profesora na platformie Moodle. Wprowadzenie tego typu wykładów sprawiło nie tylko wzrost zainteresowania wśród studentów nową formą prowadzenia zajęć, ale także umożliwiło zorganizowanie wykładów ze światowej klasy specjalistą w dziedzinie elastyczności na Politechnice Poznańskiej.

\section{PODSUMOWANIE}

Podsumowując stwierdzić można niewątpliwe, że realizacja projektów zrealizowanych przy wsparciu finansowym z funduszy UE stwarza nowe perspektywy realizacji programów nauczania na specjalności TOB. Realizacja opisanych dwóch projektów umożliwiła osiągnięcie następujących korzyści:

1. Stworzenie alternatywnej opcji studiów Master ukierunkowanych na osiągnięcie nowych kompetencji przez przyszłych menedżerów budownictwa (języki obce, przedsiębiorczość, innowacyjność, analiza case study, itp.)

2. Możliwości wprowadzenia nowych metod dydaktycznych (aktywność podczas wykładów-seminariów, praca zespołowa) oraz rozwiązań technicznych (transmisja on-line wykładów z innego uniwersytetu).

3. Możliwości rozwoju kadry (doskonalenie umiejętności, kontakty z partnerami, nowi pracownicy)

4. Nawiązanie kontaktów międzyuczelnianych oraz z organizacjami branżowymi krajowymi i zagranicznymi.

5. Wytyczenie dalszych kierunków współpracy dydaktyczno-naukowej w sytuacji pozyskania nowych partnerów.

6. Podniesienie prestiżu specjalności z korzyścią dla studentów, partnerów z przemysłu, jak i pracowników PP.

7. Możliwość skonsolidowania zespołu wokół projektów realizowanych z wykorzystaniem idei pracy zespołowej.

Projekty realizowane na Politechnice Poznańskiej w ramach funduszy z Unii Europejskiej przyczyniają się do zwiększenia możliwości, jakie uczelnia może zaproponować obecnym i przyszłym studentom. Dodatkowo projekty te są skierowane na zacieśnienie współpracy z przemysłem, co powoduje, że absolwent uczelni jest w stanie łatwiej znaleźć pracę, i niejednokrotnie płynnie przechodzi z poziomu stażysty na stanowisko pracownika danej firmy. Przyszła oferta uczelni w zakresie dydaktyki specjalistycznej będzie także poszerzona o wspólne studia podyplomowe MBA z zakresu budownictwa, które umożliwią systematyczne podnoszenie kwalifikacji przez naszych absolwentów. 